\title{
ISOLATION AND IDENTIFICATION OF AZOTOBACTER OF SOME TYPE OF LAND USE IN JEGU VILLAGES
}

\author{
Ni Nengah Soniari* and I Wayan Dana Atmaja \\ Department of Agroecotechnology, Faculty of Agriculture, Udayana University, Bali \\ "Corresponding author: nengahsoniari@unud.ac.id
}

\begin{abstract}
Conventional farming systems have a negative impact on the life of Azotobacter. Through the results of this study, we want to provide information on the existence of Azotobacter in several rhizosphere of cultivated plants, and looking for isolates that have advantages as biofertilizers and decomposers. This research is an exploration of bacteria Azotobacter spp. from several plant rhizosphere namely: organic and inorganic rice paddy, cassava, coconut, and chocolate. Three samples was taken from each type of land use, so that the number of isolate sources were 15 samples. All analyzes were conducted at Soil Biology Laboratory, Faculty of Agriculture Udayana University. This study aims to find isolates of Azotobacter spp. which is superior to be utilized as biofertilizer and decomposer. Parameters used to support isolation and identification results are total population of bacteria Azotobacter spp., soil respiration, gram staining, halo zone and optical density. The results showed that organic rice rhizosphere was the best isolate source compared with inorganic rice rhizosphere, coconut, cassava and chocolate. Isolate from this organic rice rhizosphere has the highest total population $\left(40.10 \mathrm{cfu} \times 107 \mathrm{~g}^{-1}\right.$ soil), on positive catalase test yield bubbles and optical density (average 1.217ABS at $550 \mathrm{~nm}$ wavelength). While the superior isolates of Azotobacter spp. As biofertilizer and decomposer candidates are TSO2 isolates (samples

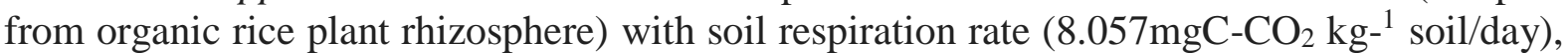
high optical density (1.147 ABS on spectrophotometer with $550 \mathrm{~nm}$ wavelength) and highest halo zone diameter $(10 \mathrm{~mm})$.
\end{abstract}

Keywords: Isolation, rhizosphere, Azotobacter spp., biofertilizer, decomposer

\section{INTRODUCTION}

The fulfillment of the need for food makes the farmers / entrepreneurs in the field of agriculture trying to increase agricultural production in various ways, such as inorganic fertilization of rapid response, the use of seeds of high nutrient and exploit the soil with intensive planting with one plant species. This incident resulted in depleted soil nutrient, land degradation and other land damage such as heavy metal pollution in agricultural land. After the phenomenon occurs, eventually making farmers begin to switch to nature (back to nature), and explore the natural potential of nature.

Azotobacter is one of the important bacteria and is very useful in human life and environmental sustainability. The statement is not excessive because of the many roles that are carried by these bacteria, such as free-life (non-symbiotic) nitrogen retardants, as a producer of IAA (Indol Acetic Acid) (Wedhastri, 2002), can be utilized as a biofertilizer and bioaccumulation as well as a 
reliable decomposer. Azotobacteria can help synthesize biologically active substances that can increase seed germination, stand and plant growth such as vitamin $\mathrm{B}$, indole acetic acid, gibberellins, and cytokines (Wedhastri, 2002; Ahmad. 2005 and Husen, 2003) Azotobacter is a non-simbiotic gramnegative aerobic bacteria which functions as a free $\mathrm{N}$ binder so that these bacteria have an influence on soil physical and chemical properties in increasing soil fertility (Supriyadi, 2009). Nitrogen in the form of Ammonium inside Azotobacter inoculant can support soil bearing capacity to support plant growth (Hindersah and Simarmata, 2004), and some examples of azotobacter that produce fitohormone especially cytokines are: A. croococcum, A. beijerinckii, A. paspali and A. vinelandi (Taller \& Wong 1989). Azotobacter has also been on inoculation in other plants and effective improve growth and production crops such as sugar cane, corn, cotton, rice, tomatoes, eggplants, chilies, cabbage, and potatoes as well as estate crops like coffee, tea, cocoa, coconut and cardamom (Mahajan et al., 2003). The results of Khotimah and Zulaika, (2014) study, suggested that Azotobacter can accumulate up to $87 \%$ and resistant to mercury $\left(\mathrm{HgCl}_{2}\right)$ to a concentration of $5 \mathrm{mg} / \mathrm{L} \mathrm{HgCl}_{2}$. They also facilitate the mobility of heavy metals in the soil, thus enhancing bioremediation of soil from heavy metals, such as Cadmium, Mercury and Lead (Chen, et al.1995)

Jegu Village's research location is a potential agricultural area, has low pollution, so the possibility of acquisition of isolates has good opportunity in terms of quality of isolated indigenous bacteria. The village also has a history of land use that is diverse as rice fields (conventional and organic), and gardens (coconuts, cocoa, cassava), and fields, so that all the sources of isolates we need in this study are in this village.

The urgency of this research is to motivate the community / farmers to reduce the use of inorganic fertilizer and substitute it with biofertilizer, and utilization of Azotobacter for handling agricultural waste to be composted and returned to agricultural land as organic fertilizer.

The abundance of these bacteria in farmland, especially in the rhizosphere, provides an opportunity for researchers to isolate isolates to be tested for their ability or superiority as biofertilizers or decomposers. this research is our field as researcher from soil and environment laboratory especially soil biology, very concentrated and want to contribute to the development of science is applicative and useful for the community. The aim of this study : (1) to find out isolates of Azotobacter, spp on some land use types in Jegu Village, Penebel District, Tabanan, (2) To identify Isolate of Azotobacter spp. 
(to find the type of indigenous Azotobacter present in the study site), (3) to select of isolates that have superior ability as a biological fertilizer and biodecomposer.

\section{MATERIALS AND METHODS}

The research was conducted at Soil and Environmental Laboratory of Faculty of Agriculture, Udayana University by taking soil samples from rhizosphere of agricultural crops and plantations in Jegu village, from April to October 2017. This study used several media types such as Nutrient agar, Nutrient Broth, and specific media for Azotobacter (Ashby), as well as eqipment such as autoclave and spectrophotometer, and tools such as Bunsen, petridish, test tube, electric scales, pipette and others. The table 1 shows the location of sampling and the code.

Table 1. Code and source of isolates

\begin{tabular}{ll}
\hline Sample code & \multicolumn{1}{c}{ Rhizosphere plant } \\
\hline PSO1 & Organic Rice Field location 1 \\
PSO2 & Organic Rice Field location 2 \\
PSO3 & Organic Rice Field location 3 \\
PSA1 & Inorganic Rice Field location 1 \\
PSA2 & Inorganic Rice Field location 2 \\
PSA3 & Inorganic Rice Field location 3 \\
KTL1 & Cassava tree location 1 \\
KTL2 & Cassava tree location 2 \\
KTL3 & Cassava tree location 3 \\
KLP1 & Coconut Location 1 \\
KLP2 & Coconut Location 2 \\
KLP3 & Coconut Location 3 \\
CKL1 & Chocolate location 1 \\
CKL2 & Chocolate location 2 \\
CKL3 & Chocolate location 3 \\
\hline
\end{tabular}

Parameters that are tested and measured in this study were bacteria that used gram staining, microscopic tests and catalase tests. Soil respiration uses the Verstraete method (Anas, 1989); the number of colonies using the pour cup method; halo zone to determine the ability of Azotobacter in decompose cellulose using CMC media, and optical density obtained using a spectrophotometer.

Flow Chart of Research:

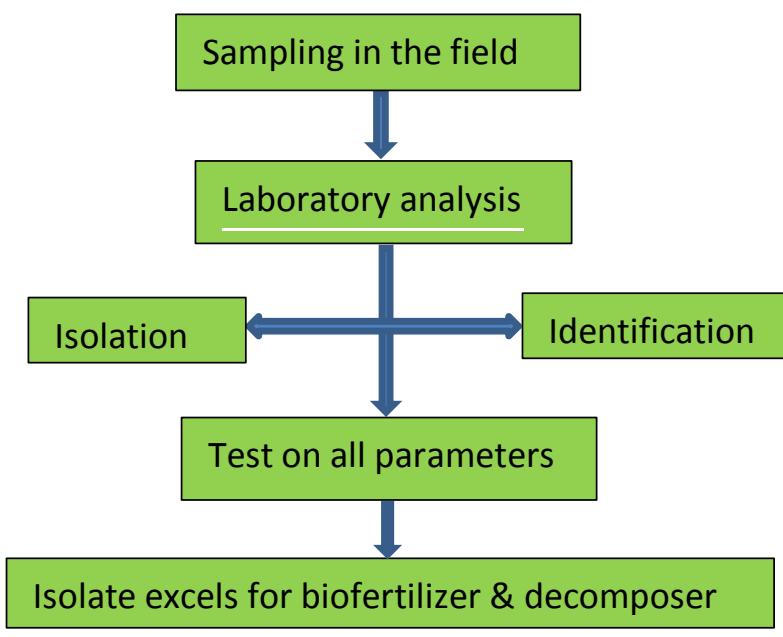

\section{RESULTS AND DISCUSSION}

1. Observation of Total Number of Bacteria (Azotobacter spp.)

Observation of total bacteria Azotobacter using specific Asbhy`s media (Nurmas, 2014) with dilution series of $10^{5}$, $10^{6}$ and $10^{7}$. (Table 2).

Table 2. Total Azotobacter spp. 


\begin{tabular}{cccc}
\hline Number & Sample & Total $\left(\mathbf{c f u} \mathbf{~ 1 0}^{\mathbf{7}} \mathbf{g}^{\mathbf{- 1}}\right.$ soil) & Description (colony size) \\
\hline 1. & KLP1 & 18.2 & medium \\
2. & KLP2 & 19.3 & Medium \& small \\
3. & KLP3 & 20.15 & medium \\
4. & CKL1 & 0.5 & large \\
5. & CKL2 & 0.3 & large \\
6. & CKL3 & 0.52 & Large \& small \\
7. & TSO1 & 36.05 & Large \& small \\
8. & TSO2 & 40.10 & Large \& small \\
9. & TSO3 & 34.01 & Large \& small \\
10. & TSA1 & - & - \\
1. & TSA2 & - & - \\
12. & TSA3 & - & - \\
13. & KTL1 & 15.05 & small \\
14. & KTL2 & 17.1 & small \\
15. & KTL3 & 21.03 & small \\
\hline
\end{tabular}

These observations show that in paddy fields using inorganic fertilizers and chemical pesticides (TSA1, TSA2 and TSA3) there is no growth of azotobacter, whereas in rhizosphere of organic paddy rice, cassava, coconut and cocoa, the presence of azotobacter is still high (Fig. 1).

Population of Azotobacter spp. most commonly found in organic rice rhizosphere (TSO2) of $40.10 \mathrm{cfu} \quad .10^{7} \mathrm{~g}^{-1}$ soil. This indicates that the use of pesticides and chemical fertilizers threatens the life of beneficial bacteria such as Azotobacter spp., so the biological balance in the soil is disturbed, and in the fields with the organic treatment and natural atmosphere, the comfort of life for Azotobacter is guaranteed.

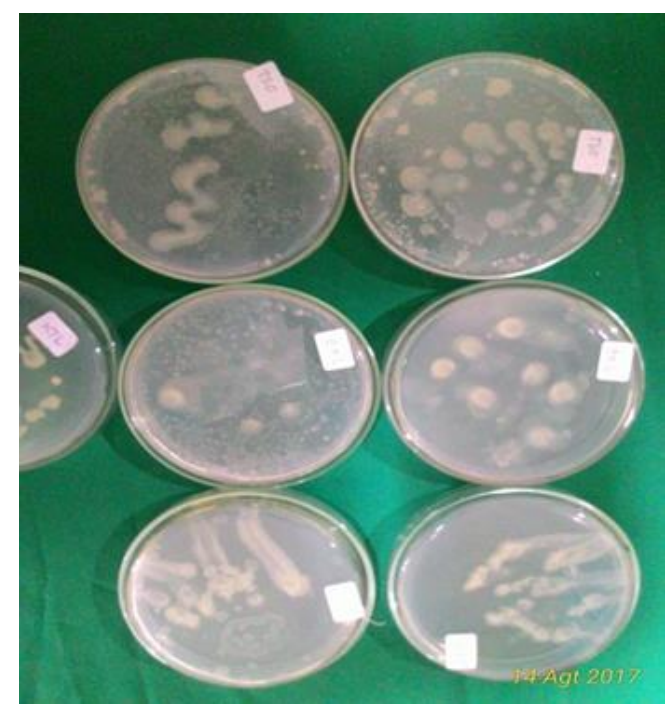

Fig. 1. Colonies of Azotobacter spp.

2. Soil Respiration

Activity of microorganisms in the soil can be seen from the $\mathrm{CO}_{2}$ produced during respiration and measured by Vertsraete method (Anas, 1989). Observations of soil respiration are shown in Fig. 2 and Table 3. 

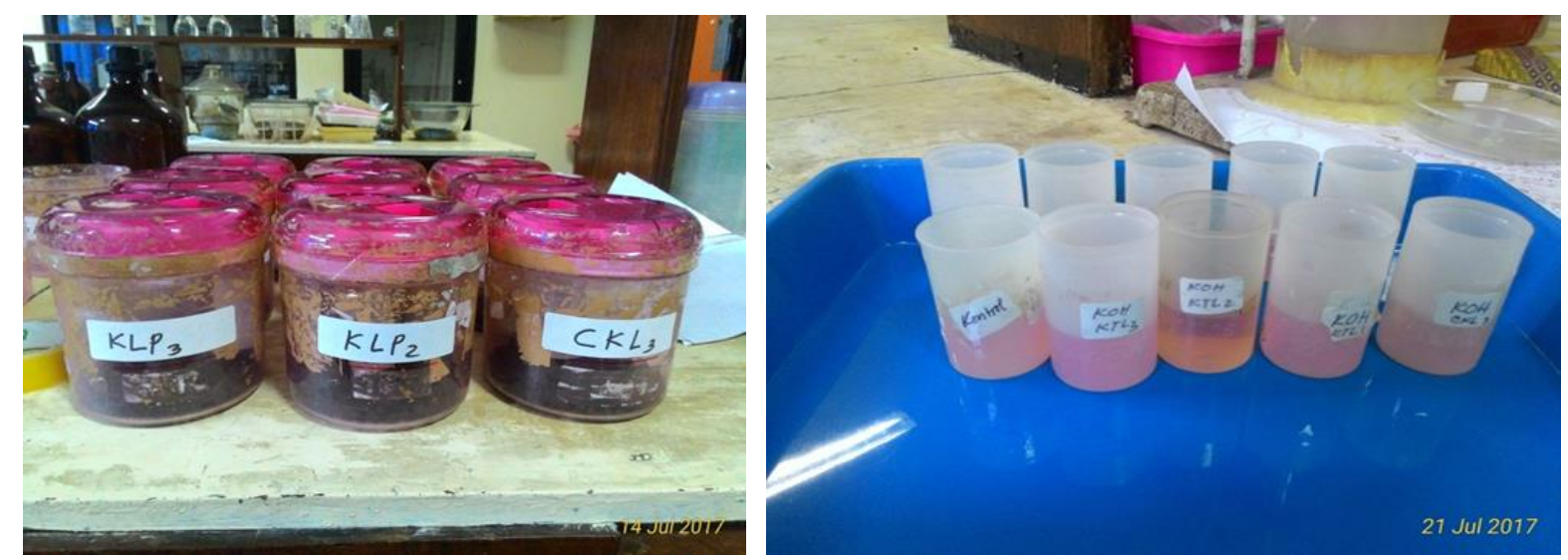

Fig. 2. Measurement of Soil Respiration

Table 3. Soil respiration ( $\mathrm{mgC}-\mathrm{CO}_{2} / \mathrm{kg}$ of soil / day)

\begin{tabular}{ccc}
\hline Number & sample & Soil respiration $\left(\mathbf{m g C}-\mathbf{C O}_{\mathbf{2}} / \mathbf{~ k g ~ o f ~ s o i l ~ / ~ d a y ) ~}\right.$ \\
\hline 1. & KLP1 & 5.314 \\
2. & KLP2 & 8.143 \\
3. & KLP3 & 8.229 \\
4. & CKL1 & 4.886 \\
5. & CKL2 & 4.371 \\
6. & CKL3 & 6,527 \\
7. & KTL1 & 5.057 \\
8. & KTL2 & 8.229 \\
9. & KTL3 & 5.914 \\
10. & TSO1 & 6.686 \\
11. & TSO2 & 8.057 \\
12. & TSO3 & 5.143 \\
13. & TSA1 & 7.286 \\
14. & TSA2 & 6.600 \\
15. & TSA3 & 8.057 \\
\hline
\end{tabular}

The highest soil micro-organism higher the soil activity the more fertile the activity was found in the cassava rhizosphere soil.

(KTL) and coconut (KLP) followed by TSO2 and TSA3 samples. The soil respiration data provides an overview of the 3. Catalase Test

Observation on bacterial ability to activity for the whole soil microorganism, so it can not be used to specify the activity of produce catalase enzyme was done by catalase test as on Table 4.

Azotobacter in particular, but generally the 
Table 4. Catalase test $\left(\mathrm{H}_{2} \mathrm{O}_{2}, 3 \%\right)$

\begin{tabular}{cccc}
\hline Number & Sample code & Test results (bubbles) & Information \\
\hline 1 & KLP1 & + & a little \\
\hline 2 & KLP2 & + & a little \\
3 & KLP3 & + & medium \\
4 & CKL1 & + & many \\
5 & CKL2 & + & many \\
6 & CKL3 & + & many \\
7 & TSO1 & + & medium \\
8 & TSO2 & + & medium \\
9 & TSO3 & + & medium \\
10 & KTL1 & + & many \\
11 & KTL2 & + & many \\
12 & KTL3 & + & many \\
\hline
\end{tabular}

All culture samples grown in Asbhy media, have the ability to produce $\mathrm{O}_{2}$ with the characteristic of releasing bubbles upon spillage of $\mathrm{H}_{2} \mathrm{O}_{2}, 3 \%$. These results are consistent with the statement that Azotobacter also produces the enzyme catalase and the reductase enzyme (Nath,et.al. 2015). Catalase is an enzyme that can catalyze the breakdown of $\mathrm{H}_{2} \mathrm{O}_{2}$ (hydrogen peroxide) into water and $\mathrm{O}_{2}$. The chemical reactions that occur when the colony is spilled into $\mathrm{H}_{2} \mathrm{O}_{2}$ are as follows:

$$
\mathrm{H}_{2} \mathrm{O}_{2} \underset{\text { Peroksidase }}{\stackrel{\text { Catalase }}{\longrightarrow}} \mathrm{H}_{2} \mathrm{O}+1 / 2 \mathrm{O}_{2} \text { (air bubble) }
$$

\section{Bacterial gram staining}

Gram staining is an important part of the identification of the type of bacteria, whether including gram negative or positive (Willey et al., 2009) The results of the gram staining showed that isolated isolates were entirely gram-negative in red or pink and rod-shaped, indicating that these isolates had characteristics characterized by Azotobacter spp (Fig. 3.).

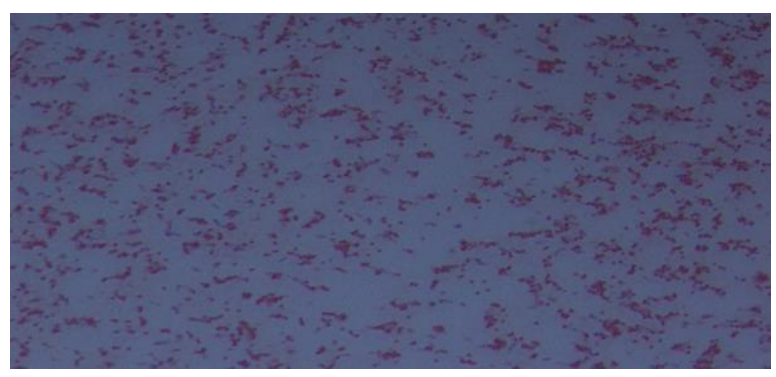

Fig. 3. Gram staining result

\section{Optical Density}

The growth rate of Azotobacter spp. in liquid media (Nutrient broth) is reflected by the optic density measured by the spectrophotometer of 550 wavelength, presented in Table 5. 
Table 5. Spectrophotometer reading results

\begin{tabular}{ccc}
\hline Number & Sample code & Optical density (ABS) \\
\hline 1. & KLP1 & 0.9044 \\
2. & KLP2 & 0.8670 \\
3. & KLP3 & 0.8205 \\
4. & CKL1 & 0.7824 \\
5. & CKL2 & 0.7310 \\
6. & CKL3 & 0.7010 \\
7. & TSO1 & 1.2026 \\
8. & TSO2 & 1.1467 \\
9. & TSO3 & 1.3002 \\
10. & KTL1 & 0.9825 \\
11. & KTL2 & 0.6100 \\
12. & KTL3 & 0.7065 \\
\hline
\end{tabular}

The population density of the field. It turns out that isolates from the Azotobacter spp. in the nutrient broth can be measured in quality with a spectrophotometer, where the more cloudy parameters

the medium means the higher the optical density and the denser population. In this measurement, organic wetland rhizosphere samples (TSO) occupy the highest position, meaning that Azotobacter spp. grows and develops rapidly in natural organic atmosphere. Biochemical tests on several prospective isolates aim to select characteristics that are in accordance with the characteristics of Azotobacter, which are then tested and measured in their ability to multiply through measuring optical density, the ability to decompose cellulose by looking at the extent of the halo zone. All the test sets above are useful for the initial selection of isolates that have advantages as biofertilizers and decomposers, before being applied in the

\section{CONCLUSIONS}

From the results and discussion above, it can be concluded that organic rice field is a good source of isolates for exploration of the Azotobacter spp. Isolate Azotobacter spp. the best for biofertilizer and decomposer is the TSO2 isolate, in terms of its ability to produce catalase enzymes, has rapid growth and development, in comparison with isolates from other sources of isolates.

Other biochemical tests are required to provide more accurate results in determining the best isolate candidates, and application test to indicator plants 
(biofertilizer candidates) as well as compost (candidate decomposer).

\section{REFERENCES}

Ahmad, F., Ahmad, M., \& Khan, S. (2005). Indole Acetic Acid production by the indigenous isolates of Azotobacter and Pseudomonas fluorescent in the presence and absence of tryptophan. Turk. J. Biol.29: 29-34.

Anas, I. (1989). Biologi Tanah dalam praktek. Pusat Antar Universitas Bioteknologi IPB Bogor.

Chen J. H., Czajka, D. R., Lion, L. W., Shuler, M. L., \& Ghiorse, W. C. (1995). Trace metal mobilization in soil by bacterial polymers. Environmental Health Perspect. 103 (1): $\quad$ 53-58. doi: 10.1289/ehp.95103s 153

Hindersah, R., \& Simarmata, T. (2004). Potensi rizobakteri azotobacter dalam meningkatkan kesehatan tanah. Jurnal Natur Indonesia 5(2):127-133

Husen, E. (2003). Screening of Soil Bacteria for Plant Growth Promotion Activities In Vitro. Indonesian Journal of Agricultural science. 4(1) 2003: 27-31.

Khotimah, K., \& Zulaika, E. (2014). Azotobacter Sebagai Bioacumulator Merkuri. Jurnal Sains dan Seni vol. 3 no. 2. Institut Teknologi Sepuluh Nopember

Mahajan, A., Choudhary, A. K., Jaggi, R. C., \& Dogra, R. K. (2003). Importance of Biofertilizers in Sustainable Agriculture. Farmers' Forum 3 (4): 17-19.
Nath, J., Das, A., \& Ray, L. (2015). Biosorption of Malachite Green from Aqueous Solution by Dry Cells of Bacillus cereus M1 16 (MTCC 5521).Journal of Environmental Chemical Engineering, 3(1):386 -394 Nurmas, A., Nofianti, Rahman, A., \& Khaeruni, A. (2014) . Eksplorasi dan Karakterisasi Azotobacter Indigenous Untuk Pengembangan Pupuk Hayati Tanaman Padi Gogo Lokal di Lahan Marginal. Jurnal Agroteknos Vol 4 (2) pp. 127 - 133. Kendari.

Ratna, I. (2007). Fiksasi N Biologis pada Ekosistem Tropis.Jatinangor:Fakultas Pertanian UNIVERSITAS PADJADJARAN

Supriyadi, M. (2009). Pengaruh Pupuk Kandang dan NPK terhadap Populasi Azotobacter dan Budidaya Cabai (Capsicum Annum). www.biosains.mipa.uns.ac,id.

Diakses pada tanggal 18 Juni 2018.

Taller, B. J., \& Wong, T. Y. (1989). Cytokinins in Azotobacter vinelandii Culture Medium Appl. Environ. Microbiol. 55: 266-267

Pemerintahan Desa Jegu. 2010. Profil Pembangunan Desa Jegu tahun 2010

Wedhastri, S. (2002). Isolasi dan Seleksi Azotobacter spp. Penghasil Faktor Tumbuh dan Penambat Nitrogen dari Tanah Masam. Jurnal Ilmu Tanah dan Lingkungan Vol 3 (1) pp 45-51. Yogyakarta.

Willey, J. M., Sherwood, L. M., \& Woolverton, C. J. (2009). Prescott's Principles of Microbiology. New York: McGraw-Hill. 